\section{Coastal waters in jeopardy}

\section{Washington}

WITHouT some intervention, coastal waters and estuaries around the United States will become increasingly polluted. But efforts to evaluate current conditions and predict those in the future are hampered by a paucity of data from many regions of the country, says a report released last week by the Congressional Office of Technology Assessment (OTA).

Curtailing waste disposal activities and runoff is the only clear choice for improving the quality of estuaries and coastal waters, according to the report. One simple solution is to move dumping activities further off-shore, but this presents technical, logistical and economic problems. Reducing waste generation, recycling wastes and treating waste material all alleviate damage to the environment, but cannot solve the problem entirely.

The slightly better news is that the open ocean is in better shape than the coastal environment. In contrast to estuaries and coastal waters, relatively little dumping and discharge takes place at sea, although the report predicts there will be increasing pressure to dump sewage sludge offshore, rather than in coastal waters. Evaluation of the impact of open ocean dumping is also hampered by lack of information. Nicholas Sundt, an analyst for OTA, says that poor information could be masking problems.

Although water quality in certain coastal waters and estuaries has improved in the past, these have typically been the ones in the worst shape, says Sundt. Economic conditions have forced many areas to abandon treatment. Expensive though treatment programmes were in the past, new efforts will cost even more. Since communities are often far removed from the effects of their disposal activities, it can be hard to generate political support for solving the problem.

The situation is not hopeless. Congress this year passed an act authorizing $\$ 18,000$ million in grants and loans for sewage treatment facilities. The Environmental Protection Agency (EPA) is developing management programmes for coastal waters and estuaries. But there is no integrated national strategy for improving water quality. With its penchant for understatement, the OTA report states that given the threats to these waters, "it now seems appropriate that Congress and EPA begin developing a systematic framework to implement the water quality approach more extensively." Joseph Palca

The report "Wastes in Marine Environment" is available as OTA-O-334 from the US Government Printing Office.

\title{
Oil explorers make waves in Alaskan tundra reserve
}

\section{Washington}

US Interior Secretary Donald Hodel has enraged environmentalists in two controversial moves designed to open up new areas to oil exploration. Last week he recommended to Congress that oil development be allowed in the coastal plain of the Arctic National Wildlife Refuge in Alaska. A few days later, he followed that with a five-year plan that would allow offshore drilling in areas off the California, Florida and Alaska coasts.

In recommending drilling in the Arctic National Wildlife Refuge he went beyond an earlier Interior Department report (Nature 324, 401; 1980) that argued for delaying development in a part of the refuge used for calving by the 18,000 -head 'Porcupine' caribou herd. Hodel now claims the report was in error in saying the herd would be harmed by oil development.

Susan Alexander of the Wilderness Society, one of several conservation groups opposing development, said that it was a case of "altering facts that didn't support development goals". The area, she says, is one of the most extensive undeveloped landscapes left in North America. Now, conservationists will aim to "educate the Congress and the American public so they'll feel the same way about the refuge as they do about the Grand Canyon or Yellowstone".

Business and oil industries praised the shift in Alaskan policy but were much less happy about the new plan for offshore drilling. Despite opening what environmentalists regard as some of the "most sensitive coastal and marine areas" to oil drilling it stopped far short of an earlier Interior Department proposal that the entire continental shelf be made available.

Both the Alaskan and offshore proposals will now face fierce battles in Congress. The oil industry will be arguing that new finds are essential to halt the increasing dependence of the US on foreign oil supplies. But a final decision on the Alaskan refuge is unlikely until after the next Presidential election given the number of voters who favour conservation. And if Congress does not reject the offshore drilling plan it can block drilling leases later.

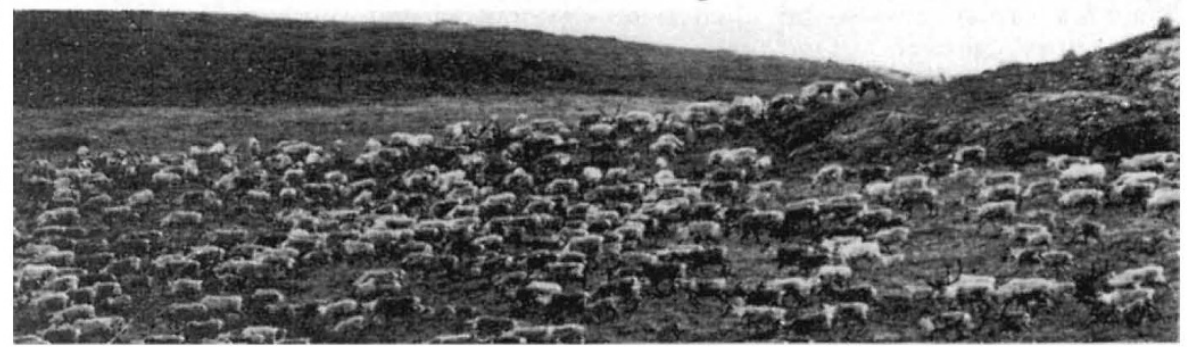

\section{Developer pays for King's College move}

\section{London}

A NOVEL kind of collaboration between UK universities and commerce has emerged. Mr Kenneth Baker, Secretary of State for Education and Science, has agreed that King's College London (KQC) should enter into a partnership with a property developer to secure a new site for itself. In return for financing the purchase of the lease on an empty government building, the commercial partner will be allowed half the profits from the development of the college's existing properties.

$\mathrm{KQC}$ has been formed within the past four years by the amalgamation of the old King's College with two smaller units of the University of London, Queen Elizabeth College and Chelsea College, whence KQC. Academic development has been impeded by the lack of space on the main site in the Strand. But earlier this year, Baker said the government would not provide special assistance to the college for purchase of a lease on Cornwall House, across the Thames from the Strand site.

Under the deal now struck, the commercial developer will put up the $£ 1.25$ million required to purchase the lease of the building. The college will then have four years in which to raise the funds needed to fit the building for its new purpose. The hope is that the funds required, which may amount to $£ 20$ million, will come from using the vacant sites for other purposes. One of the sites concerned occupies 4.5 acres of Kensington in west London, an expensive residential district, where a piece of road big enough to park a single automobile is worth $£ 10,000$.

This development suggests that the government appears prepared to contemplate radical changes of the rule that the proceeds of the sale of academic properties should be used exclusively for academic purposes (or even returned to the Treasury). 